\title{
Geospatial Assessment of Ambient Air Quality Footprints in Relation to Urban Landuses in Nigeria
}

\author{
Josiah Nwabueze Obiefuna ${ }^{1, *}$, Ebin Okah Inah ${ }^{1}, J_{0 y}$ William Undie Atsa ${ }^{2}$, Emmanuel Asuquo Etim $^{3}$ \\ ${ }^{1}$ Department of Geography and Environmental Science, Faculty of Environmental Sciences, University of Calabar, P.M.B. 1115, \\ Calabar, Nigeria \\ ${ }^{2}$ Department of Environmental Resource Management, Faculty of Environmental Sciences, University of Calabar, P.M.B. 1115, \\ Calabar, Nigeria \\ ${ }^{3}$ Department of Geography, School of Arts and Social Sciences, Cross River State College of Education, Akamkpa, CRS, Nigeria \\ *Corresponding Author: JoeObiefuna@Gmail.com
}

Received November 5, 2021; Revised December 8, 2021; Accepted December 29, 2021

\section{Cite This Paper in the following Citation Styles}

(a): [1] Josiah Nwabueze Obiefuna, Ebin Okah Inah, Joy William Undie Atsa, Emmanuel Asuquo Etim, "Geospatial Assessment of Ambient Air Quality Footprints in Relation to Urban Landuses in Nigeria," Environment and Ecology Research, Vol. 9, No. 6, pp. 426 - 446, 2021. DOI: 10.13189/eer.2021.090609.

(b): Josiah Nwabueze Obiefuna, Ebin Okah Inah, Joy William Undie Atsa, Emmanuel Asuquo Etim (2021). Geospatial Assessment of Ambient Air Quality Footprints in Relation to Urban Landuses in Nigeria. Environment and Ecology Research, 9(6), 426 - 446. DOI: 10.13189/eer.2021.090609.

Copyright $\odot 2021$ by authors, all rights reserved. Authors agree that this article remains permanently open access under the terms of the Creative Commons Attribution License 4.0 International License

\begin{abstract}
Ambient air pollution is a global concern. It accounts for an estimated 4.2 million deaths yearly as a result of its ability to cause stroke, lung cancer, heart disease and chronic respiratory diseases. It has also been estimated that about 91 percent of the world's population lives in places, mostly urban centres, where air quality levels exceed World Health Organization (WHO) limits. Fortunately, efforts are regularly made in most developed countries to monitor and reduce the level of air pollution and ameliorate its negative consequences. Unfortunately, the case is not the same in most developing countries of which Nigeria is a member, as air pollution status is rarely monitored religiously. This study geospatially assessed ambient air quality footprints vis-à-vis urban land uses in Calabar Metropolis, Nigeria. Data on emission level of CO, $\mathrm{NO}_{2}, \mathrm{SO}_{2}, \mathrm{H}_{2} \mathrm{~S}$, and $\mathrm{SPM}_{2.5}$ were collected for 6 months in both dry and wet seasons in the year 2020, using Crowcon Gasman, while point coordinates were collected using Garmin GPSMap 60CSx device. Geographic Information Systems (GIS) infrastructure was deployed to generate the ambient air quality maps for the metropolis. Descriptive and parametric analytical techniques were also deployed, based on the objectives of the study. From findings, F-ratio is significant for both season and land use for all the tested parameters (F-ratio for season is $\mathrm{F}(1,3224)=574.516$, at $\mathrm{p}<0.05$, while for land use, $\mathrm{F}(3,3224)=429.946$, at $\mathrm{p}<0.05)$. The interaction between seasons and land use (season* land use) for all the parameters is also significant. It was
\end{abstract}

concluded that there is a significant variation in air quality $\left(\mathrm{CO}, \mathrm{NO}_{2}, \mathrm{SO}_{2}, \mathrm{H}_{2} \mathrm{~S}\right.$, and $\mathrm{SPM}_{2.5}$ ) in Calabar Metropolis in relation to either land use types or seasons of the year. It was therefore recommended that there should be protection of residential land uses to avoid encroachment by incompatible uses that cause pollution.

Keywords Geospatial, Air Quality, Footprints, Urban Land Uses, Environmental Pollution

\section{Introduction}

Every piece of land has a use to which it must be put depending on its natural endowment and profitability. This is termed landuse. Again, land use is the ordered arrangement of socio-economic activities and inputs on a certain land cover type to produce change or maintain it [1]. In a broad perspective, land use is the classification and location of physical structures and conforming activities within a defined region [2]. Land use provides a more livable community to the residents and the work force in a defined urban area. A well organised land use enhances, on a long-term basis, the economic climate as well as green and clean urban areas. It also preserves natural heritage, optimizes recreation and eliminates congestion occasioned by vehicular activities. 
Some of the major contaminants of air in urban areas worldwide are the by-products of landuses such as carbon monoxide $(\mathrm{CO})$, carbon dioxide $\left(\mathrm{CO}_{2}\right)$, sulphur dioxide $\left(\mathrm{SO}_{2}\right)$, oxides of nitrogen ( $\left.\mathrm{NOx}\right)$, volatile organic carbons (VOCs), suspended particulate matters (SPM), etc. Notably, VOCs consist of hydrocarbons. It has been acknowledged that ozone is formed when VOC is mixed with nitrogen oxides and carbon monoxide. Ozone is also a principal pollutant in many urban areas. In most West African cities such as Nigeria, as well as other major cities of the advanced world, outdoor ambient air pollution has been identified as a major threat to human health $[3,4,5,6,7,8,9]$. Poor ambient air quality is capable of negatively altering the average life span of individuals, communities or even nations that are constantly exposed to it.

According to the global estimates by the United Nations Environment Programme (UNEP), a lot of persons amounting to over one billion breathe unhealthy air [10].

Finally, since economic activities constitute or result to pollution of varying degree, it is pertinent that various land uses in Nigeria, which represent diverse economic activities be scrutinized for various pollutants to ensure that they conform to acceptable standards, otherwise, the people and property would be endangered. Yuvaraj [11] stated that there is a likelihood of impact of man's activity on the natural ecosystem through land use/land cover patterns and changes. In addition, [12] stated that land conflicts in urban areas are usually dynamic in nature and therefore, maintained that it is necessary to consolidate and restructure land use, tenure, and acquisition in order to minimize pollution and improve environmental quality. According to him, land re-adjustment has the potential to improve efficiency, productivity and optimal transformation of urban land use for the purpose of attaining sustainable and just spatial planning.

This research geospatially examined the relationship between urban land uses and ambient air quality footprints in Nigeria urban centres with special emphasis on Calabar Metropolis. Finally, the research was conducted in the year 2020.

\section{The Problematic}

Generally, it is pertinent to state that there exists thematic and scanty literature on air quality for Calabar Metropolis. Most of these studies focused on air quality micro themes such as air quality status occasioned by transportation activities, or air quality impact from a selected industrial facility, or within a selected processing plant. For instance, [13] examined the Regional Trend in Ambient Air Quality Footprints in Calabar Urban, Nigeria but failed to comprehensively assess and depict air quality in relation to existing landuses, (spatial) as well as temporal dimension. Besides, studies by [14] as well as [15] were not wide with respect to spatial scope and parameters that were examined. While [15] examined Total Suspended Particulate (TSP) matters, ignoring major or criteria pollutants, [14] concentrated on volumetric transport and air quality relationship. It is worthy to note that a comprehensive air quality study should test for one or more elements from among the criteria pollutants. In addition, $[16,17,18]$ concentrated only on noise level and landslide susceptibility assessment in Cross River State using geospatial techniques.

More importantly, these studies did not assess air quality holistically in relation to all land use types on a city-wide scale. The studies were therefore limited in scope pointing to the fact that there is dearth of relevant air quality data for the metropolis. Moreover, these studies were not captured in spatial context. This means that they are grossly lacking on the aspect of contemporary methodology, since they did not employ environmental visioning tools, and therefore, did not graphically visualize air quality status in the metropolis as it is often said by geographers that "a map speaks more than a thousand words" [19]. Lack of visually projected information on air quality would hamper certain developmental decisions. For example, air quality status taken over a period of time and analyzed graphically would give information on the level of visibility and effluents that are attainable at certain locations and at given time periods. This information would be of immense benefit during transportation planning.

However, there seems to be a sporadic location and ubiquitous distribution of various forms of economic activities as well as other informal enterprises in Calabar Metropolis. All these ultimately give rise to air pollution. Sule [20] states that land use planning is made in order to ensure that the best land is given the best use so that there would be increased profitability as well as minimized incompatibilities and conflicts arising from air and noise pollution.

\section{Aim and Objectives of the Study}

The aim of this research was to geospatially assess Ambient Air Quality Footprints in Calabar metropolis, Nigeria, in relation to existing dominant landuse elements. The objectives are as follows:

1. Assess the spatial variation of air quality status in relation to land use types in Calabar Metropolis, Nigeria.

2. Assess the seasonality differential in air quality status in Calabar Metropolis.

3. To generate ambient air quality footprint maps of the metropolis, using the GIS infrastructure. 
A research hypothesis was set and tested in this research. It states that there is no significant variation in ambient air quality status in relation to either land use types or seasons of the year in the study area being Calabar Metropolis. Calabar is the capital city of Cross River State (FIG.1). Calabar is located between longitudes $8^{\circ} 18^{\prime}$ and $8^{0} 25^{\prime \prime}$ East of the Greenwich meridian and latitudes $4^{\circ} 55^{\prime}$ and $5^{0} 10^{\prime}$ North of the Equator. It is sandwiched between the Great Kwa River to the East and the Calabar River to the west. Calabar Metropolis, comprising Calabar Municipality and Calabar South Local Government Areas has a total land area of $1480 \mathrm{sq} \mathrm{kms}$. Calabar is bounded to the North by Odukpani Local Government Area, to the East by Akpabuyo Local Government Area.

\section{Research Methodology}

\subsection{Types and Sources of Data}

The study relied on primary data on ambient air quality status across various landuses as well as data on seasonality variation in air quality status in Calabar Metropolis, Nigeria. Data were expressed in parts per million (ppm) scale.

Data were acquired using several automated data loggers named Crowcon Gasman and a Garmin GPSMap. Dataset included logged figures on the level of pollutants and suspended particulate matter from various locations within identified landuses as well as the GPS coordinates for the locations.

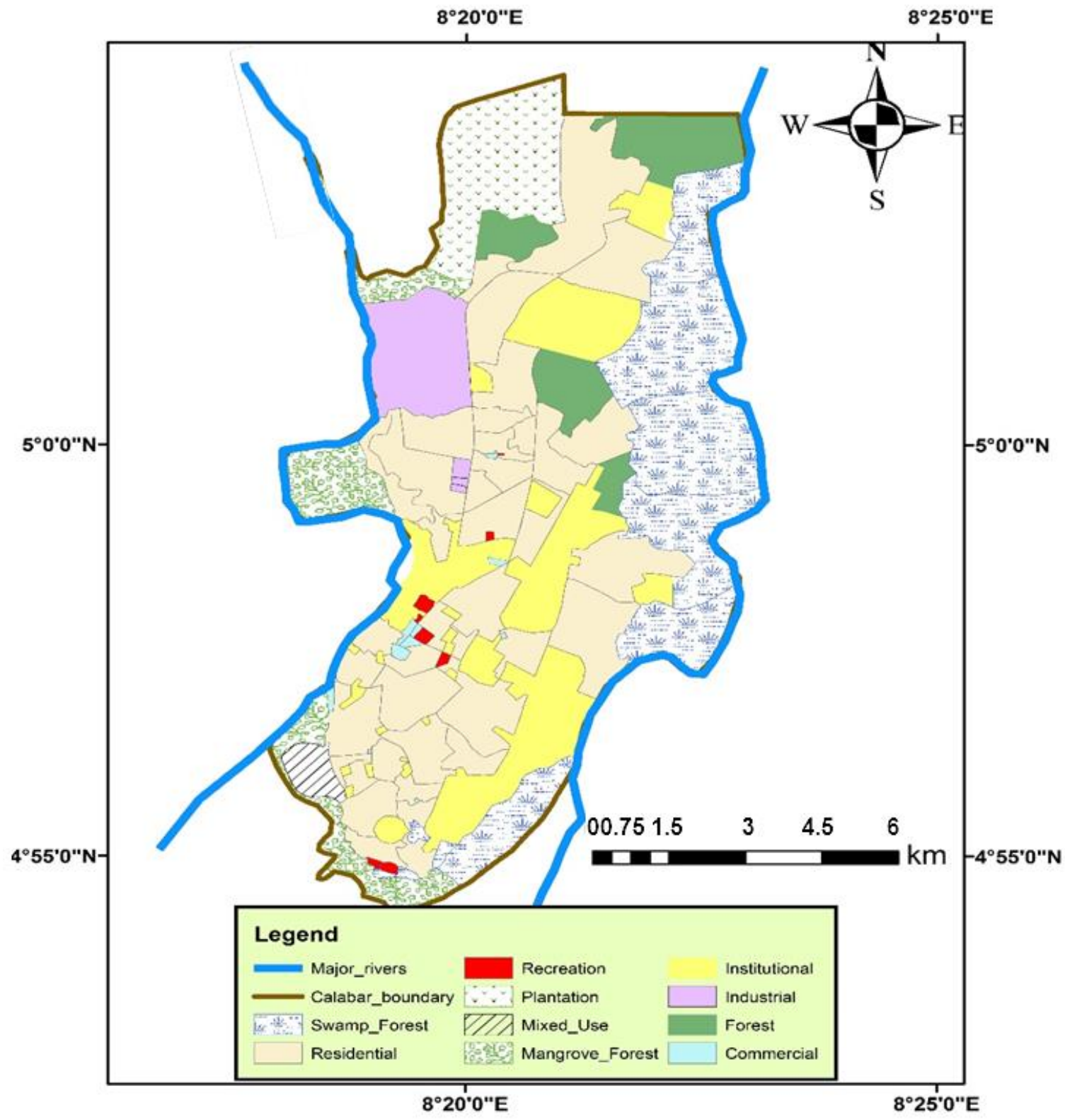

Source: Obiefuna, Njar and Bisong (2021)

Figure 1. Land use map of Calabar Metropolis showing the study area 


\subsection{Selection of Monitoring Sites and Data Collection}

Air quality data collection was carried out at each selected location within a land use using a real-time, automated air quality monitor, mounted on a ground-based platform/tripod, or held at a height of a range of between 1.5 and 2.0 meters from the ground.

Data readings were made once in the afternoon between 12 noon and $12.30 \mathrm{pm}$. This represents the peak period when economic activities are at their optimum. The duration of data collection lasted for a period of four months. In the rainy (wet) season, readings were taken between July and August, while in the dry season, readings were taken between November and December.

Harmful pollutants and particulate matters occasioned by economic activities were measured because they have been identified as being very injurious to human health and the environment, while $\mathrm{PM}_{2.5}$ is said to be a causal agent for cancer, heart or respiratory disease [21].

\subsection{Sampling Procedure}

Stratification and randomization were employed to group and randomly select points from each land use for proper representation. Though a total of 24 locations were identified on the transportation land use, 7 were selected. On this landuse, data were acquired along road nodes on major road network, roundabout and parks. For the industrial landuse, data were acquired from both the minor road intersections/junctions within the zone as well as 10 metres from the pollution sources. A total of 18 locations were identified in the industrial landuse, while five (5) locations were selected. For the commercial landuse, data were acquired from the pollution sources after having identified them. 22 locations were identified while 7 locations were selected. With regards to the residential neighbourhood, data were acquired from minor road intersections and from other emission points. A total of 23 locations were identified while seven (7) locations were also selected. Presented below is table 1 , which shows a total of 26 sample points representing 30 percent of the total observed points from all land uses. This decision for 30 percent selection was based on [22] which states that a sample fraction of 10 percent is deemed adequate as no serious research can progress with a sample fraction less than 10 percent. This means that the 30 percent sample fraction employed in this research is very adequate and representative. Selection was done using a row by column digital random number generator. The sample points have been depicted (FIG. 2).

\subsection{Techniques for Data Analysis}

Sourced data were subjected to geospatial and statistical analytical manipulations using GIS, inferential and descriptive statistics. The output was in averages, tables, charts, graphs and composite maps showing air quality footprints for the study area.

\section{Test of Hypothesis}

$\mathrm{H}_{0}$ : There is no significant variation in air quality in Calabar Metropolis in relation to either land use type or season of the year.

$\mathrm{H}_{1}$ : There is a significant variation in air quality in Calabar Metropolis in relation to either land use type or season of the year.

A two-way analysis of variance (ANOVA) or factorial analysis of variance was used to test this hypothesis. The mathematical definition of ANOVA is given as:

$$
\begin{gathered}
\sum_{i j} \sum_{i j}^{\mathrm{n}}\left(X_{i j}-\overline{\mathrm{X}} \quad\right)^{2}=(x+a)^{n} \\
=\sum_{i j} \mathrm{ni}\left(X_{1}-\overline{\mathrm{X}}\right)^{2}+\sum_{i j}\left(X_{i j}\right) \\
\mathrm{TSS}=\mathrm{BSS}+\mathrm{WSS}
\end{gathered}
$$

Where:

TSS $=$ Total Sum of Squares (total mean squares of all locations)

BSS = Between Group Sum of Squares (the sum of square of observations made within each landuse)

WSS = Within Group Sum of Squares (the sum of square of observations made across different landuses)

$\mathrm{K}=$ Number of Samples (26 points)

$\mathrm{N}=$ Number of Observations (number of all observations in all locations)

$X_{i j}=$ Value of the ith and jth observation, $\overline{\mathrm{X}}=$ Mean, $X_{i}=$ Mean for the ith sample

$\sum \sum=$ Summation of all items in the matrix i.e. all " $\mathrm{k}$ " or " $n$ " (emission level across the days of the week over different time periods in all locations). 
Table 1. Sampled points with their GPS coordinates

\begin{tabular}{|c|c|c|c|c|c|}
\hline $\begin{array}{l}\mathbf{S} / \\
\mathbf{N}\end{array}$ & Land use Type/ Location & Activity Type & $\begin{array}{l}\text { GPS } \\
\text { Lat. }\end{array}$ & $\begin{array}{c}\text { Value } \\
\text { Long. }\end{array}$ & Prevailing Activities/pollutants \\
\hline 1. & Industrial-EPZ & Administrative Block & 5.024907 & 8.322707 & Administrative Block \\
\hline 2. & Industrial-EPZ & $\begin{array}{l}\text { By Dangote Flour Mills, } \\
\text { Haulage, processing }\end{array}$ & 5.018985 & 8.322473 & $\begin{array}{l}\text { Processing, Haulage, vehicles, } \\
\text { trucks }\end{array}$ \\
\hline 3. & Industrial-EPZ & $\begin{array}{l}\text { M-Saleh Industry: } \\
\text { Fabrication, welding }\end{array}$ & 5.02485 & 8.32704 & $\begin{array}{l}\text { Point source: fabrication, welding, } \\
\text { metal cutting, smoothening, } \\
\text { welding. }\end{array}$ \\
\hline 4. & Industrial-EPZ & $\begin{array}{l}\text { Stone Craft Industry: } \\
\text { Processing }\end{array}$ & 5.02563 & 8.32704 & $\begin{array}{l}\text { Point source: Cutting and polishing } \\
\text { of stones, marble production }\end{array}$ \\
\hline 5. & Industrial-EPZ & $\begin{array}{l}\text { Rosa Mystica Tank farm, } \\
\text { Combination Industries: } \\
\text { processing }\end{array}$ & 5.028472 & 8.32248 & Tank farm, storage, processing \\
\hline 6. & $\begin{array}{l}\text { Transportation: Muritala } \\
\text { Muhammed highway }\end{array}$ & Road Node: Mobil by MCC & 4.98720 & 8.343341 & $\begin{array}{l}\text { Line sources: vehicles, dust } \\
\text { particles }\end{array}$ \\
\hline 7. & $\begin{array}{l}\text { Transportation } \\
\text { (Eleven-Eleven area) }\end{array}$ & Round About & 4.96384 & 8.32488 & $\begin{array}{l}\text { Line sources: vehicles, dust } \\
\text { particles }\end{array}$ \\
\hline 8. & $\begin{array}{l}\text { Transportation (Effio-Ette } \\
\text { area) }\end{array}$ & Round About & 4.993898 & 8.345098 & $\begin{array}{l}\text { Line sources: vehicles, dust } \\
\text { particles }\end{array}$ \\
\hline 9. & $\begin{array}{l}\text { Transportation (Etta-Agbor } \\
\text { Road) }\end{array}$ & $\begin{array}{l}\text { Round About (Unical Main } \\
\text { Gate) }\end{array}$ & 4.95254 & 8.33921 & $\begin{array}{l}\text { Line sources: vehicles, dust } \\
\text { particles }\end{array}$ \\
\hline 10. & $\begin{array}{l}\text { Transportation (Etta-Agbor } \\
\text { Road) }\end{array}$ & Round About (by IBB Rd & 4.95933 & 8.32164 & $\begin{array}{l}\text { Line sources: vehicles, dust } \\
\text { particles }\end{array}$ \\
\hline 11. & $\begin{array}{l}\text { Transportation (Ekpoabasi } \\
\text { Road) }\end{array}$ & Road Node by CRUTECH & 4.93151 & 8.3284 & $\begin{array}{l}\text { Line sources: vehicles, dust } \\
\text { particles }\end{array}$ \\
\hline 12. & Transportation (park) & Etim Edem park & 4.96039 & 8.3243 & $\begin{array}{l}\text { Line sources: vehicles, dust } \\
\text { particles }\end{array}$ \\
\hline 13. & $\begin{array}{l}\text { Commercial: Calabar Road } \\
\text { by Watt Market }\end{array}$ & By Atakpa Police Station & 4.95736 & 8.31927 & Buying and selling, vehicles \\
\hline 14. & $\begin{array}{l}\text { Commercial (Watt Market } \\
\text { Area) }\end{array}$ & By Nelson Mandela & 4.956593 & 8.32212 & Buying and selling, vehicles \\
\hline 15. & $\begin{array}{l}\text { Commercial (Watt Market } \\
\text { area) }\end{array}$ & By Goldie & 4.958283 & 8.32317 & Buying and selling, vehicles \\
\hline 16. & $\begin{array}{l}\text { Commercial (Watt Market } \\
\text { area) }\end{array}$ & $\begin{array}{l}\text { By Calabar road round } \\
\text { about }\end{array}$ & 4.957348 & 8.320463 & Buying and selling, vehicles \\
\hline 17. & $\begin{array}{l}\text { Commercial(Marian } \\
\text { Market) }\end{array}$ & Point source pollution & 4.9753 & 8.33922 & $\begin{array}{l}\text { Buying and selling, grinding, } \\
\text { vehicles }\end{array}$ \\
\hline 18. & $\begin{array}{l}\text { Commercial (Marian } \\
\text { Market) }\end{array}$ & Point source of pollution & 4.97559 & 8.33927 & $\begin{array}{l}\text { Buying and selling, vehicles, } \\
\text { grinding }\end{array}$ \\
\hline 19. & $\begin{array}{l}\text { Commercial: Marian Market } \\
\text { area }\end{array}$ & $\begin{array}{l}\text { Commercial activities, } \\
\text { waste dump }\end{array}$ & 4.976893 & 8.338185 & Buying and selling, vehicles, \\
\hline 20. & Residential: Ekorinim & $\begin{array}{l}\text { Residential: by Redeemed } \\
\text { Church }\end{array}$ & 4.99921 & 8.32295 & Residential, mobility \\
\hline 21. & Residential: Ekorinim II & Residential: By NPA & 4.999927 & 8.325983 & Residential, mobility \\
\hline 22. & Residential: Satellite town & $\begin{array}{l}\text { Residential: By Children of } \\
\text { Promise School }\end{array}$ & 4.959683 & 8.354402 & Residential, mobility \\
\hline 23. & Residential (State Housing) & $\begin{array}{l}\text { Residential:State Housing } \\
\text { by Atekon Drive }\end{array}$ & 4.980188 & 8.33551 & Residential, mobility \\
\hline 24. & Residential (State Housing) & By the police Station & 4.98532 & 8.33952 & Residential, mobility \\
\hline 25. & $\begin{array}{l}\text { Residential (Federal } \\
\text { Housing) }\end{array}$ & $\begin{array}{l}\text { Residential: By Esien } \\
\text { Kooffreh/Police Station }\end{array}$ & 5.021298 & 8.336463 & Residential, mobility \\
\hline 26. & $\begin{array}{l}\text { Residential (Federal } \\
\text { Housing) }\end{array}$ & Residential & 5.029147 & 8.335152 & Residential, mobility \\
\hline
\end{tabular}

Source: Obiefuna, Njar and Bisong (2021) 


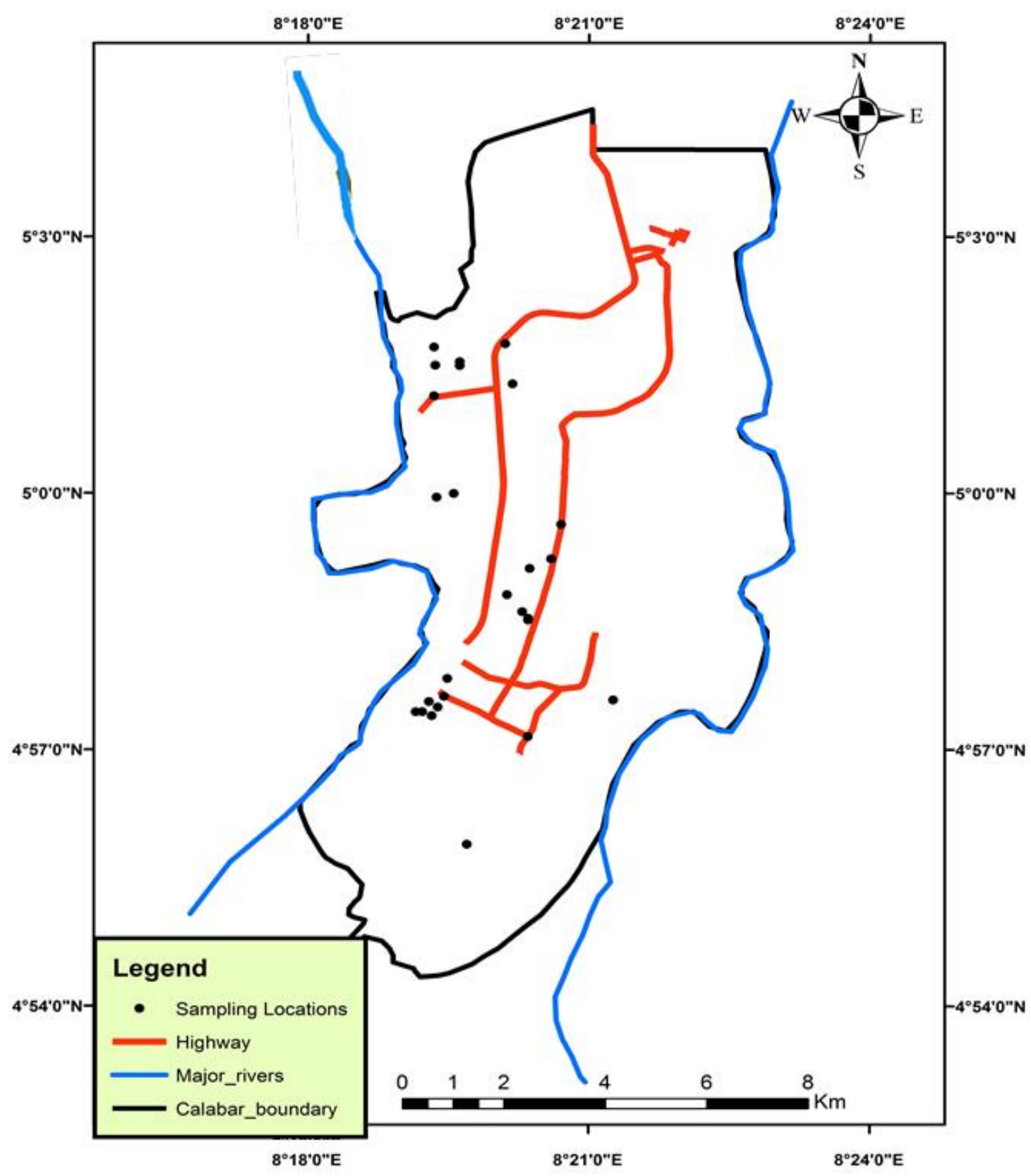

Source: Obiefuna, Njar and Bisong (2021)

Figure 2. Sampled locations across land uses in Calabar Metropolis

\section{Results/Findings}

\subsection{Spatial Analysis of Land Use Based and Seasonality Differential in Air Quality Footprints in Calabar Metropolis}

The hypothesis was tested using a two-way analysis of variance (ANOVA). Table 2 shows the descriptive statistics for $\mathrm{CO}$ in terms of the mean and standard deviation for the wet season, dry season and total over the various land uses. For example, the mean value of $\mathrm{CO}$ for industrial land use is 2.3433 in the wet season and 3.4587 in the dry season. These values have corresponding standard deviations of \pm 0.73000 and \pm 1.12405 respectively. This shows that $\mathrm{CO}$ concentration was higher in the dry season than in the wet season. Similarly, observations can be made on CO for other land uses.

Table 3 shows the test of between subject effects with $\mathrm{CO}$ as the variable of interest over the various land uses and seasons of the year. It was hypothesized as follows:

$\mathrm{H}_{0}$ : There is no significant variation in air quality $(\mathrm{CO})$ in Calabar Metropolis in relation to either land use type or season of the year.

$\mathrm{H}_{1}$ : There is a significant variation in air quality $(\mathrm{CO})$ in 
Calabar Metropolis in relation to either land use type or season of the year. From the result in table 3, the F-ratio for season is $\mathrm{F}(1,3198)=574.516, \mathrm{p}<0.05$ is significant. Similarly, for land use, F $(3,3198)=429.946, p<0.05$ is significant. For the interaction between seasons and land use (season * landuse), $\mathrm{F}(3,3198)=58.189, \mathrm{p}<0.05$ is also significant. Hence, we do not have enough evidence to retain the null hypothesis. Therefore, it was concluded that there is a significant variation in air quality (CO) in Calabar Metropolis in relation to either land use type or season of the year.

Table 2. Descriptive statistics for the analysis of $\mathrm{CO}$ across land uses

\begin{tabular}{ccccc}
\hline Season & Land use & Mean & Std. Deviation & N \\
\hline \multirow{3}{*}{ Wet season } & Industrial & 2.3433 & .73001 & 310 \\
& Transportation & 2.8467 & .67254 & 434 \\
& Commercial & 2.7493 & .67084 & 434 \\
& Residential & 1.4429 & .39254 & 434 \\
& Total & 2.3457 & .84688 & 305 \\
Dry season & Industrial & 3.4587 & 1.12405 & 427 \\
& Transportation & 2.9144 & 1.40331 & 427 \\
& Commercial & 3.5877 & .64288 & 427 \\
& Residential & 2.2422 & .59354 & 1586 \\
& Total & 3.0194 & 1.12572 & 615 \\
& Industrial & 2.9010 & 1.09923 & 861 \\
& Transportation & 2.8805 & 1.10024 & 861 \\
& Commercial & 3.1685 & .77916 & 861 \\
& Residential & 1.8426 & .64248 & 3198
\end{tabular}

Dependent Variable: CO

Source: Analysis by the Author, 2020.

Table 3. Tests of Between-Subjects Effects for CO

\begin{tabular}{ccccccc}
\hline Source & $\begin{array}{c}\text { Type III Sum of } \\
\text { Squares }\end{array}$ & df & Mean Square & F & Sig. & Partial Eta Squared \\
\hline Corrected Model & $1366.034^{\mathrm{a}}$ & 7 & 195.148 & 285.698 & .000 & .383 \\
Intercept & 22978.640 & 1 & 22978.640 & 33640.982 & .000 & .913 \\
Season & 392.426 & 1 & 392.426 & 574.516 & .000 & .152 \\
Land use & 881.031 & 3 & 293.677 & 429.946 & .000 & .286 \\
Season * Landuse & 119.239 & 3 & 39.746 & 58.189 & .000 & .051 \\
Error & 2196.705 & 3216 & .683 & & & \\
Total & 26763.091 & 3198 & & & & \\
Corrected Total & 3562.738 & 3197 & & & & \\
\hline
\end{tabular}

a. R Squared $=.383$ (Adjusted R Squared $=.382$ ). Dependent Variable: $\quad$ CO

Source: Analysis by the Author, 2020. 
The result of the post hoc test indicates a significant difference in most comparisons except between industrial and transportation land uses. The land uses that cause significant variation are the commercial and residential. This has been graphically depicted (FIG.3).

Table 4 shows the descriptive statistics for $\mathrm{NO}_{2}$ in terms of the mean and standard deviation for the wet season, dry season and total over the various land uses. For example, the mean value of $\mathrm{NO}_{2}$ for industrial land use is 0.3265 in the wet season and 0.7586 in the dry season. These values have corresponding standard deviations of \pm 0.36859 and \pm 0.72436 respectively. This shows that $\mathrm{NO}_{2}$ concentration is higher in the dry season than in the wet season. Similarly, observations can be made on $\mathrm{NO}_{2}$ for other land uses.

Table 5 shows the test of between subject effects with $\mathrm{NO}_{2}$ as the variable of interest over the various land uses and seasons of the year. It was hypothesized as follows:

$\mathrm{H}_{0}$ : There is no significant variation in air quality $\left(\mathrm{NO}_{2}\right)$ in Calabar Metropolis in relation to either land use type or season of the year.

$\mathrm{H}_{1}$ : There is a significant variation in air quality $\left(\mathrm{NO}_{2}\right)$ in Calabar Metropolis in relation to either land use type or season of the year. From the result in table 5 the F-ratio for season is $\mathrm{F}(1,3198)=1113.49, \mathrm{p}<0.05$ is significant. Similarly, for land use, F $(3,3198)=792.457, \mathrm{p}<0.05$ is significant. For the interaction between seasons and land use (season * landuse), $\mathrm{F}(3,3198)=236.546, \mathrm{p}<0.05$ is also significant. Hence, we do not have enough evidence to retain the null hypothesis. Therefore, it was concluded that there is a significant variation in air quality $\left(\mathrm{NO}_{2}\right)$ in Calabar Metropolis in relation to either land use type or season of the year.

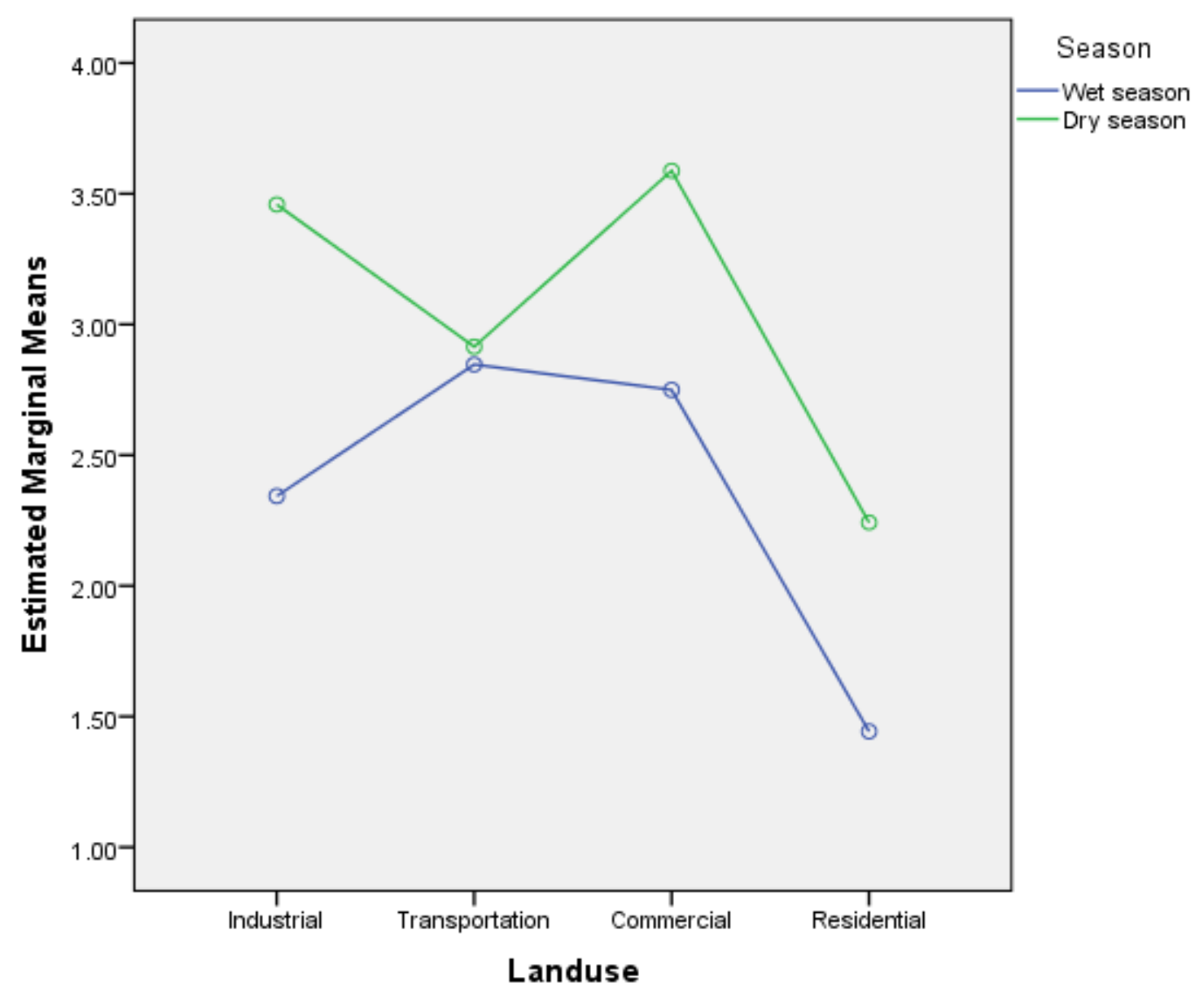

Source: Analysis by the Author, 2020.

Figure 3. Mean plot of $\mathrm{CO}$ over land use 
Table 4. Descriptive statistics for the analysis of $\mathrm{NO}_{2}$ across land uses

\begin{tabular}{|c|c|c|c|c|}
\hline Season & Land use & Mean & Std. Deviation & $\mathbf{N}$ \\
\hline \multirow{5}{*}{ Wet season } & Industrial & .3265 & .36859 & 310 \\
\hline & Transportation & 1.0506 & .26289 & 434 \\
\hline & Commercial & .8037 & .50439 & 434 \\
\hline & Residential & .3267 & .16754 & 434 \\
\hline & Total & .6500 & .46739 & 1612 \\
\hline \multirow{5}{*}{ Dry season } & Industrial & .7586 & .72436 & 305 \\
\hline & Transportation & 2.9324 & 1.42421 & 427 \\
\hline & Commercial & 1.1599 & .60121 & 427 \\
\hline & Residential & .8904 & .47664 & 427 \\
\hline & Total & 1.4874 & 1.26240 & 1586 \\
\hline \multirow{5}{*}{ Total } & Industrial & .5425 & 61359 & 615 \\
\hline & Transportation & 1.9915 & 1.39063 & 861 \\
\hline & Commercial & .9818 & .58251 & 861 \\
\hline & Residential & .6086 & .45499 & 861 \\
\hline & Total & 1.0687 & 1.03977 & 3198 \\
\hline
\end{tabular}

Dependent Variable: $\mathrm{NO}_{2}$

Source: Analysis by the Author, 2020.

Table 5. Tests of between -subjects effects for $\mathrm{NO}_{2}$

\begin{tabular}{ccccccc}
\hline Source & $\begin{array}{c}\text { Type III Sum of } \\
\text { Squares }\end{array}$ & df & Mean Square & F & Sig. & Partial Eta Squared \\
\hline Corrected Model & $1994.947^{\mathrm{a}}$ & 7 & 284.992 & 615.325 & .000 & .573 \\
Intercept & 3355.684 & 1 & 3355.684 & 7245.227 & .000 & .693 \\
Season & 515.722 & 1 & 515.722 & 1113.490 & .000 & .257 \\
Land use & 1101.098 & 3 & 367.033 & 792.457 & .000 & .425 \\
Season * Landuse & 328.675 & 3 & 109.558 & 236.546 & .000 & .181 \\
Error & 1489.516 & 3216 & .463 & & & \\
Total & 7166.467 & 3198 & & & & \\
Corrected Total & 3484.463 & 3197 & & & & \\
\hline
\end{tabular}

a. $\mathrm{R}$ Squared $=.573$ (Adjusted R Squared $=.572$ ). Dependent Variable: $\mathrm{NO}_{2}$

Source: Analysis by the Author, 2020.

In order to account for the variation in $\mathrm{NO}_{2}$ across the land uses, a post hoc test was carried out and the result indicates a significant difference in most comparisons except between industrial and residential land uses. The land uses that cause significant variation are the commercial and transportation, as graphically depicted (FIG.4).

Table 6 shows the descriptive statistics for $\mathrm{SO}_{2}$ in terms of the mean and standard deviation for the wet season, dry season and total over the various land uses. For example, the mean value of $\mathrm{NO}_{2}$ for industrial land use is 1.5381 in the wet season and 1.6538 in the dry season. These values have corresponding standard deviations of \pm 0.63464 and \pm 0.46832 respectively. This shows that $\mathrm{SO}_{2}$ concentration is higher in the dry season than in the wet season. Similarly, observations can be made on $\mathrm{SO}_{2}$ for other land uses.

Table 7 shows the test of between subject effects with
$\mathrm{SO}_{2}$ as the variable of interest over the various land uses and seasons of the year. It was hypothesized as follows:

$\mathrm{H}_{0}$ : There is no significant variation in air quality $\left(\mathrm{SO}_{2}\right)$ in Calabar Metropolis in relation to either land use type or season of the year.

$\mathrm{H}_{1}$ : There is a significant variation in air quality $\left(\mathrm{SO}_{2}\right)$ in Calabar Metropolis in relation to either land use type or season of the year. From the result in table 7, the F-ratio for season is $\mathrm{F}(1,3198)=271.213, \mathrm{p}<0.05$ is significant. Similarly, for land use, F $(3,3198)=875.421, \mathrm{p}<0.05$ is significant. For the interaction between seasons and land use (season $*$ landuse), $\mathrm{F}(3,3198)=30.004, \mathrm{p}<0.05$ is also significant. Hence, we do not have enough evidence to retain the null hypothesis. Therefore, it was concluded that there is a significant variation in air quality $\left(\mathrm{SO}_{2}\right)$ in Calabar Metropolis in relation to either land use type or season of the year. 


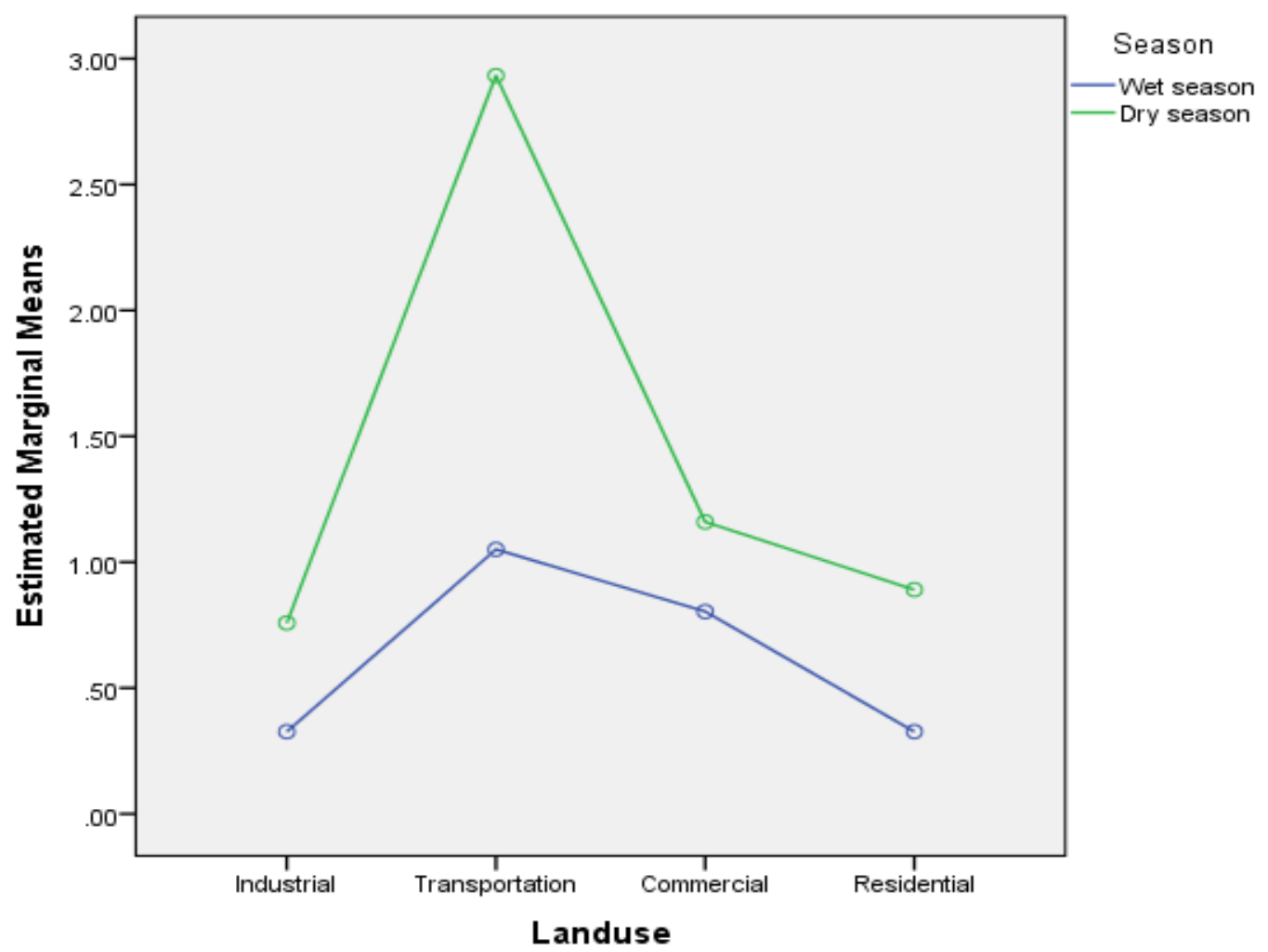

Source: Analysis by the Author, 2020.

Figure 4. Estimated marginal means of $\mathrm{NO}_{2}$ over land use

Table 6. Descriptive statistics for the analysis of $\mathrm{SO}_{2}$ across land uses

\begin{tabular}{ccccc}
\hline Season & Land use & Mean & Std. Deviation & N \\
\hline & Industrial & 1.5381 & .63464 & 310 \\
& Transportation & 2.0356 & 1.32927 & 434 \\
Wet season & Commercial & .7609 & .63466 & 434 \\
& Residential & .2409 & .20770 & 434 \\
& Total & 1.1136 & 1.08369 & 1612 \\
& Industrial & 1.6538 & .46832 & 305 \\
& Transportation & 2.9281 & 1.41756 & 427 \\
dry season & Commercial & 1.1109 & .48160 & 427 \\
& Residential & .8539 & .59108 & 427 \\
& Total & 1.6354 & 1.19471 & 1586 \\
& Industrial & 1.5960 & .56026 & 615 \\
& Transportation & 2.4819 & .44410 & 861 \\
& Commercial & .9359 & .58962 & 861 \\
& Residential & .5474 & .53858 & 861 \\
\end{tabular}

Dependent Variable: $\mathrm{SO}_{2}$

Source: Analysis by the Author, 2020.

Table 7. Tests of between - subjects effects for $\mathrm{SO}_{2}$

\begin{tabular}{ccccccc}
\hline Source & Type III Sum of Squares & Df & Mean Square & F & Sig. & Partial Eta Squared \\
\hline Corrected Model & $2138.598^{\mathrm{a}}$ & 7 & 305.514 & 432.411 & .000 & .485 \\
Intercept & 6100.973 & 1 & 6100.973 & 8635.039 & .000 & .729 \\
Season & 191.622 & 1 & 191.622 & 271.213 & .000 & .078 \\
Land use & 1855.552 & 3 & 618.517 & 875.421 & .000 & .450 \\
Season * Landuse & 63.597 & 3 & 21.199 & 30.004 & .000 & .027 \\
Error & 2272.222 & 3216 & .707 & & & \\
Total & 10501.493 & 3198 & & & & \\
Corrected Total & 4410.820 & 3197 & & & & \\
\hline
\end{tabular}

a. $\mathrm{R}$ Squared $=.485$ (Adjusted R Squared $=.484)$. Dependent Variable: $\mathrm{SO}_{2}$

Source: Analysis by the Author, 2020. 
In order to account for the variation in $\mathrm{SO}_{2}$ across the land uses, a post hoc test was carried out and the result indicates a significant difference in all between the land uses. This has been graphically depicted (FIG.5).

Table 8 depicts the descriptive statistics for $\mathrm{H}_{2} \mathrm{~S}$ in terms of the mean and standard deviation for the wet season, dry season and total. They are reported over the various land uses. For the industrial land use, table 4.31 indicates that the mean is 0.2989 for the wet season and 0.8966 for the dry season. Hence, the mean concentration of $\mathrm{H}_{2} \mathrm{~S}$ is higher for the dry season than for the wet season. Table 9 shows the test of between subject effects with $\mathrm{H}_{2} \mathrm{~S}$ as the variable of interest over the various land uses and season of the year. It was hypothesized as follows:

$\mathrm{H}_{0}$ : There is no significant variation in air quality $\left(\mathrm{H}_{2} \mathrm{~S}\right)$ in Calabar Metropolis in relation to either land use type or season of the year.

$\mathrm{H}_{1}$ : There is a significant variation in air quality $\left(\mathrm{H}_{2} \mathrm{~S}\right)$ in Calabar Metropolis in relation to either land use type or season of the year.

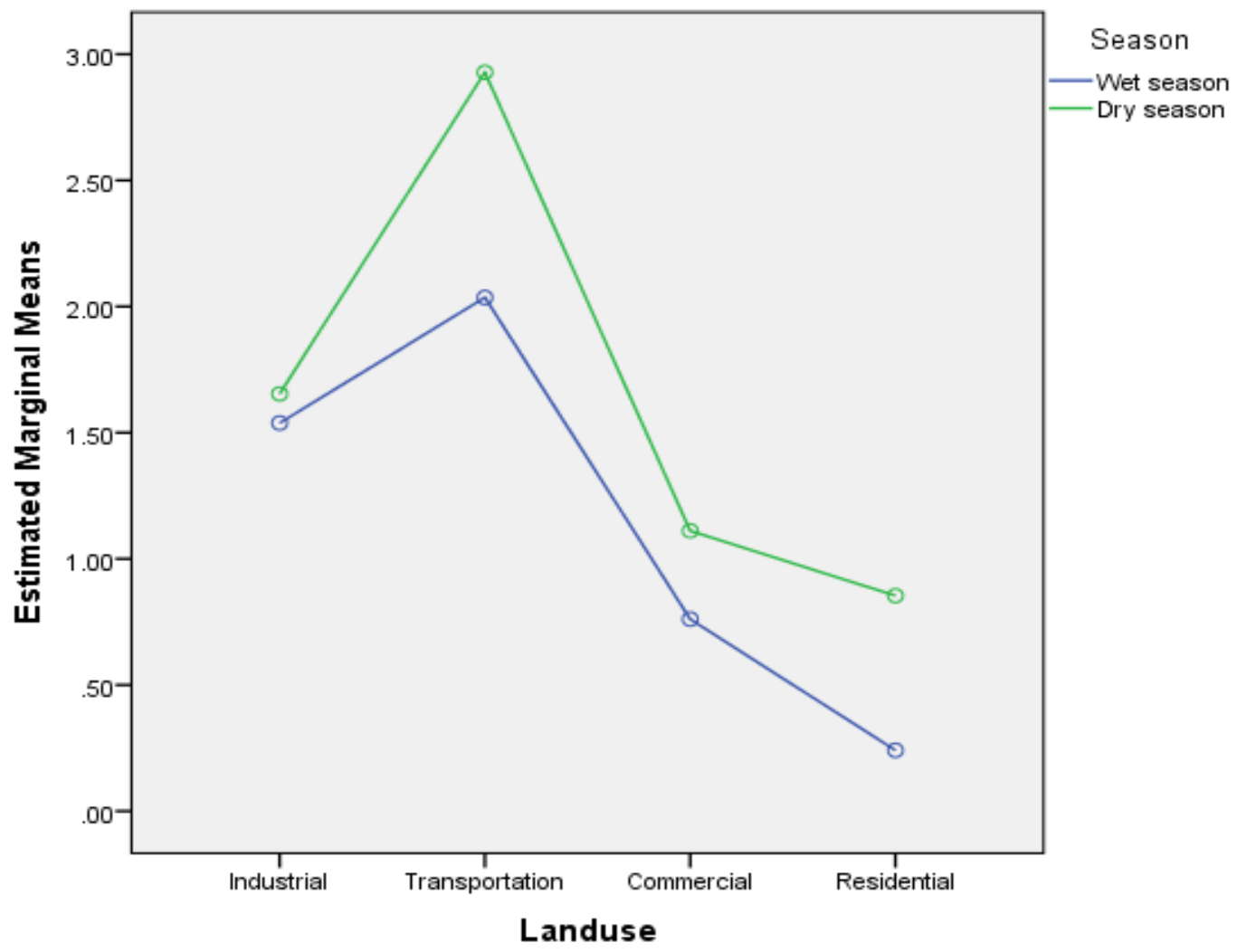

Source: Analysis by the Author, 2020.

Figure 5. Estimated marginal means of $\mathrm{SO}_{2}$ over land use

Table 8. Descriptive statistics for the analysis for $\mathrm{H}_{2} \mathrm{~S}$ across land uses

\begin{tabular}{ccccc}
\hline Season & Land use & Mean & Std. Deviation & N \\
\hline \multirow{4}{*}{ Wet season } & Industrial & .2989 & .34922 & 310 \\
& Transportation & 1.0947 & .26352 & 434 \\
& Commercial & 1.2078 & .50844 & 434 \\
& Residential & .2450 & .28479 & 434 \\
& Total & .7433 & .57414 & 1612 \\
& & & .85249 & 305 \\
dry season & Industrial & .8966 & 1.40732 & 427 \\
& Transportation & 2.8967 & .86328 & 427 \\
& Commercial & 1.8932 & .27878 & 1586 \\
& Residential & .7931 & 1.27826 & 615 \\
& Total & 1.6755 & & 861 \\
& & & .71633 & 861 \\
& Industrial & .5978 & 1.35518 & .78669 \\
\end{tabular}


Table 9. Tests of Between-Subjects Effects for $\mathrm{H}_{2} \mathrm{~S}$

\begin{tabular}{ccccccc}
\hline Source & $\begin{array}{c}\text { Type III Sum of } \\
\text { Squares }\end{array}$ & Df & Mean Square & F & Sig. & Partial Eta Squared \\
\hline Corrected Model & $2210.432^{\mathrm{a}}$ & 7 & 315.776 & 614.252 & .000 & .572 \\
Intercept & 4289.408 & 1 & 4289.408 & 8343.818 & .000 & .722 \\
Season & 650.999 & 1 & 650.999 & 1266.332 & .000 & .283 \\
Land use & 1283.315 & 3 & 427.772 & 832.108 & .000 & .437 \\
Season * Landuse & 226.729 & 3 & 75.576 & 147.012 & .000 & .121 \\
Error & 1653.288 & 3216 & .514 & & & \\
Total & 8579.621 & 3198 & & & & \\
Corrected Total & 3863.720 & 3197 & & & & \\
\hline
\end{tabular}

a. R Squared $=.572($ Adjusted R Squared $=.571)$.

Dependent Variable: $\mathrm{H}_{2} \mathrm{~S}$

Source: Analysis by the Author, 2020.

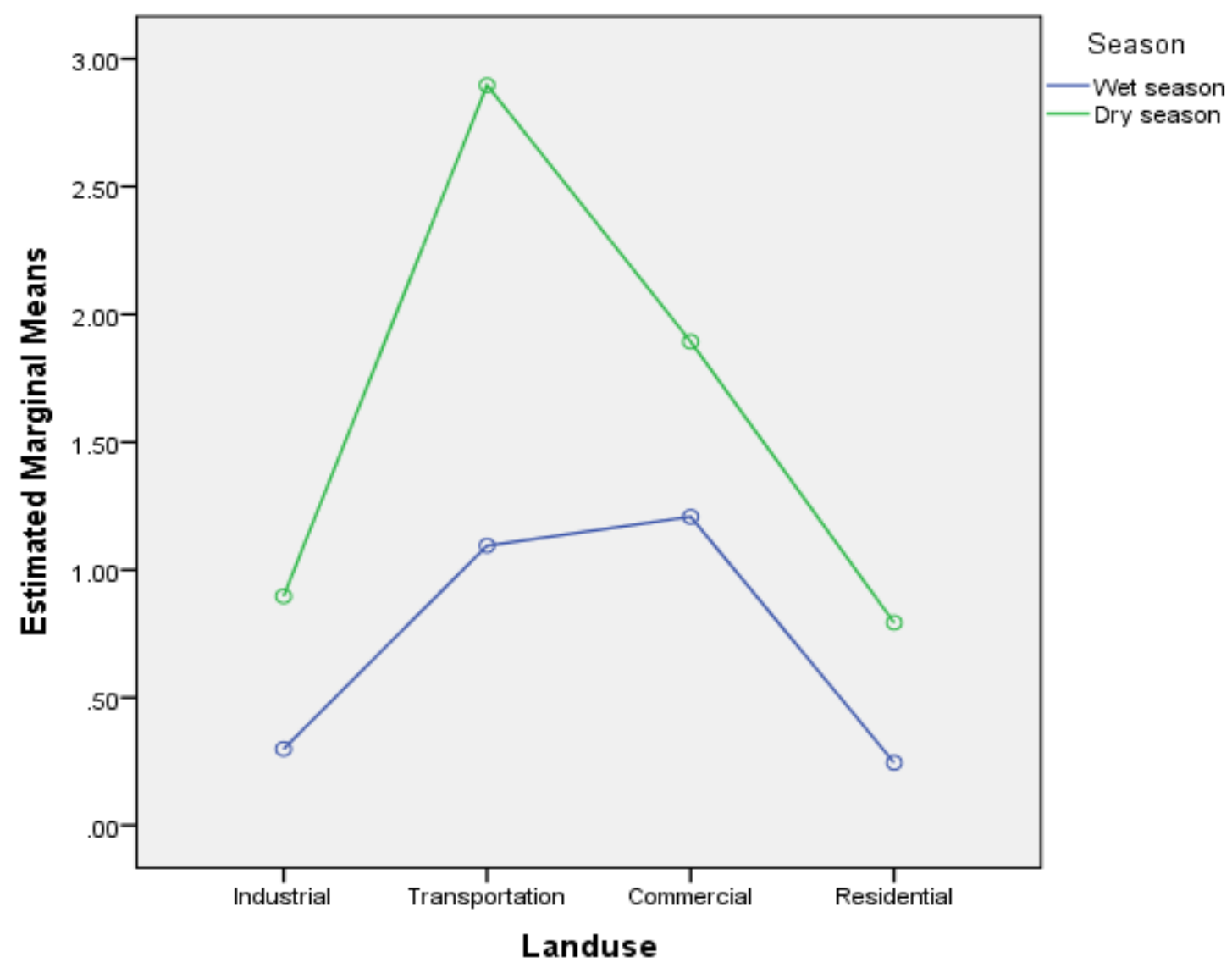

Source: Analysis by the Author, 2020.

Figure 6. Estimated marginal means of $\mathrm{H}_{2} \mathrm{~S}$ over land use

From the result in table 9 the F-ratio for season, $\mathrm{F}(1,3198)=1266.332, \mathrm{P}<0.05$ is significant. Similarly, the F-ratio for land use $\mathrm{F}(3,3198)=832.108, \mathrm{P}<0.05$ is also significant. The interaction between season and land use is again significant since $\mathrm{F}(3,3198)=147.012, \mathrm{P}<0.05$. Hence, the evidence provided by the data is not enough to retain the null hypothesis. Therefore, it was concluded that there is a significant variation in air quality in Calabar Metropolis in relation to either land use type or season of the year.
The land uses that cause significant variation are the transportation and residential, as visualized (FIG.6).

Table 11 shows the descriptive statistics for $\mathrm{SPM}_{2.5}$ in terms of the mean and standard deviation for the wet season, dry season and total over the various land uses. For example, the mean value of $\mathrm{SPM}_{2.5}$ for industrial land use is 2.6471 in the wet season and 3.9073 in the dry season. This shows that $\mathrm{SPM}_{2.5}$ is higher in the dry season than in the wet season. Similarly, observations can be made on $\mathrm{SPM}_{2.5}$ for other land uses. Table 12 shows the test of 
between subject effects with $\mathrm{SPM}_{2.5}$ as the variable of interest over the various land uses and seasons of the year. It was hypothesized as follows:

$\mathrm{H}_{0}$ : There is no significant variation in air quality $\left(\mathrm{SPM}_{2.5}\right)$ in Calabar Metropolis in relation to either land use type or season of the year.

$\mathrm{H}_{1}$ : There is a significant variation in air quality $\left(\mathrm{SPM}_{2.5}\right)$ in Calabar Metropolis in relation to either land use type or season of the year.

From the result in table 12, the F-ratio for season is
$\mathrm{F}(1,3224)=511.669, \mathrm{P}<0.05$ is significant. Similarly, for land use, $\mathrm{F}(3,3224)=299.015, \mathrm{P}<0.05$ is significant. For the interaction between seasons and land use (season $*$ landuse), $\mathrm{F}(3,3224)=211.488, \mathrm{P}<0.05$ is also significant. Therefore, it was concluded that there is a significant variation in air quality $\left(\mathrm{SPM}_{2.5}\right)$ in Calabar Metropolis in relation to either land use type or season of the year.. The land uses that cause significant variation are the commercial and residential. This has been depicted (FIG.7).

Table 11. Descriptive statistics for the analysis of $\mathrm{SPM}_{2.5}$ across land uses

\begin{tabular}{ccccc}
\hline Season & Land use & Mean & Std. Deviation & N \\
\hline \multirow{3}{*}{ Wet season } & Industrial & 2.6471 & .57872 & 310 \\
& Transportation & 3.4923 & .67118 & 434 \\
& Commercial & 3.3060 & .62331 & 434 \\
& Residential & 2.1045 & .50544 & 434 \\
& Total & 2.9060 & .82468 & 305 \\
dry season & Industrial & 3.9073 & 1.14172 & 427 \\
& Transportation & 2.9024 & 1.40953 & 427 \\
& Commercial & 4.3394 & .76751 & 427 \\
& Residential & 3.1191 & .67090 & 1586 \\
& Total & 3.5409 & 1.19109 & 615 \\
& Industrial & 3.2772 & 1.10252 & 861 \\
& Transportation & 3.1974 & 1.14207 & 861 \\
& Commercial & 3.8227 & .86920 & 861 \\
& Residential & 2.6118 & .78103 & 3198 \\
\hline
\end{tabular}

Dependent Variable: $\mathrm{SPM}_{2.5}$

Source: Analysis by the Author, 2020.

Table 12. Tests of Between-Subjects Effects for $\mathrm{SPM}_{2.5}$

\begin{tabular}{ccccccc}
\hline Source & $\begin{array}{c}\text { Type III Sum of } \\
\text { Squares }\end{array}$ & Df & Mean Square & F & Sig. & Partial Eta Squared \\
\hline Corrected Model & $1415.630^{\mathrm{a}}$ & 7 & 202.233 & 283.957 & .000 & .382 \\
Intercept & 32874.118 & 1 & 32874.118 & 46158.854 & .000 & .935 \\
Season & 364.408 & 1 & 364.408 & 511.669 & .000 & .137 \\
Land use & 638.870 & 3 & 212.957 & 299.015 & .000 & .218 \\
Season * Landuse & 451.862 & 3 & 150.621 & 211.488 & .000 & .165 \\
Error & 2290.420 & 3216 & .712 & & & \\
Total & 37204.778 & 3198 & & & & \\
Corrected Total & 3706.050 & 3197 & & & & \\
\hline
\end{tabular}

a. $\mathrm{R}$ Squared $=.382($ Adjusted R Squared $=.381)$. Dependent Variable: SPM $_{2.5}$

Source: Analysis by the Author, 2020. 


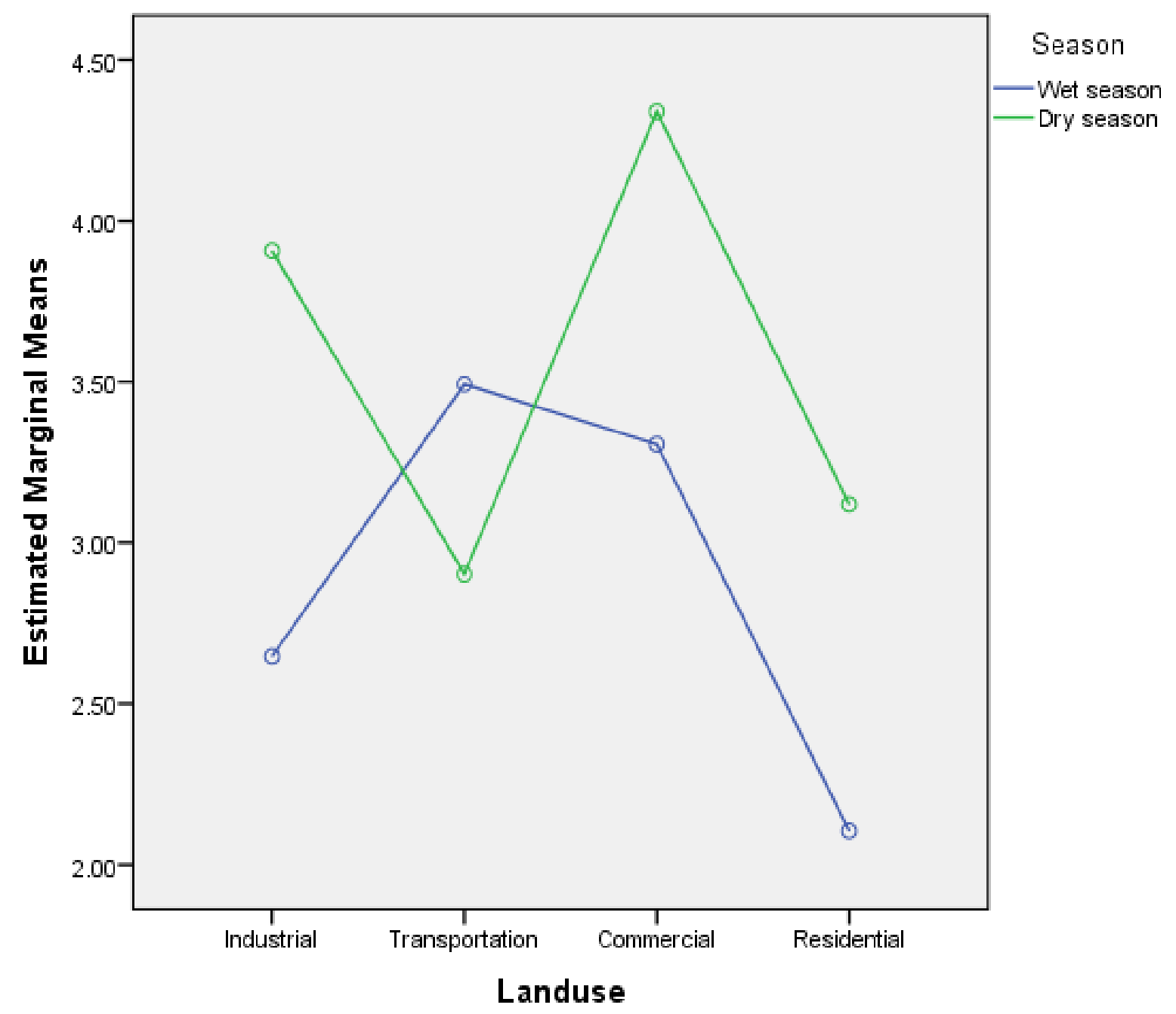

Source: Analysis by the Author, 2020.

Figure 7. Mean of $\mathrm{SPM}_{2.5}$ across the various land uses. 


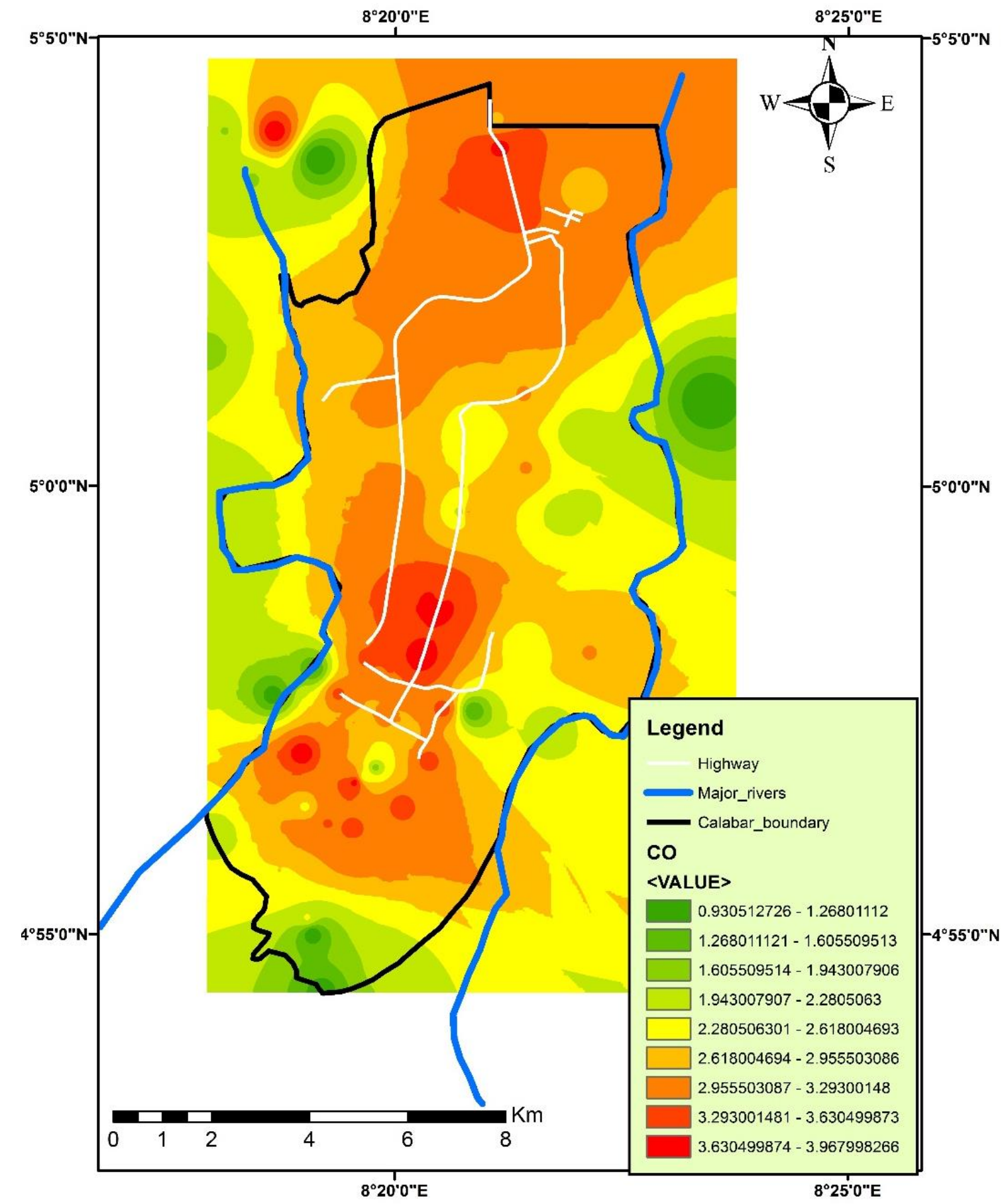

Source: Author`s GIS visualization, 2020.

Figure 8. CO footprints for Calabar Metropolis 


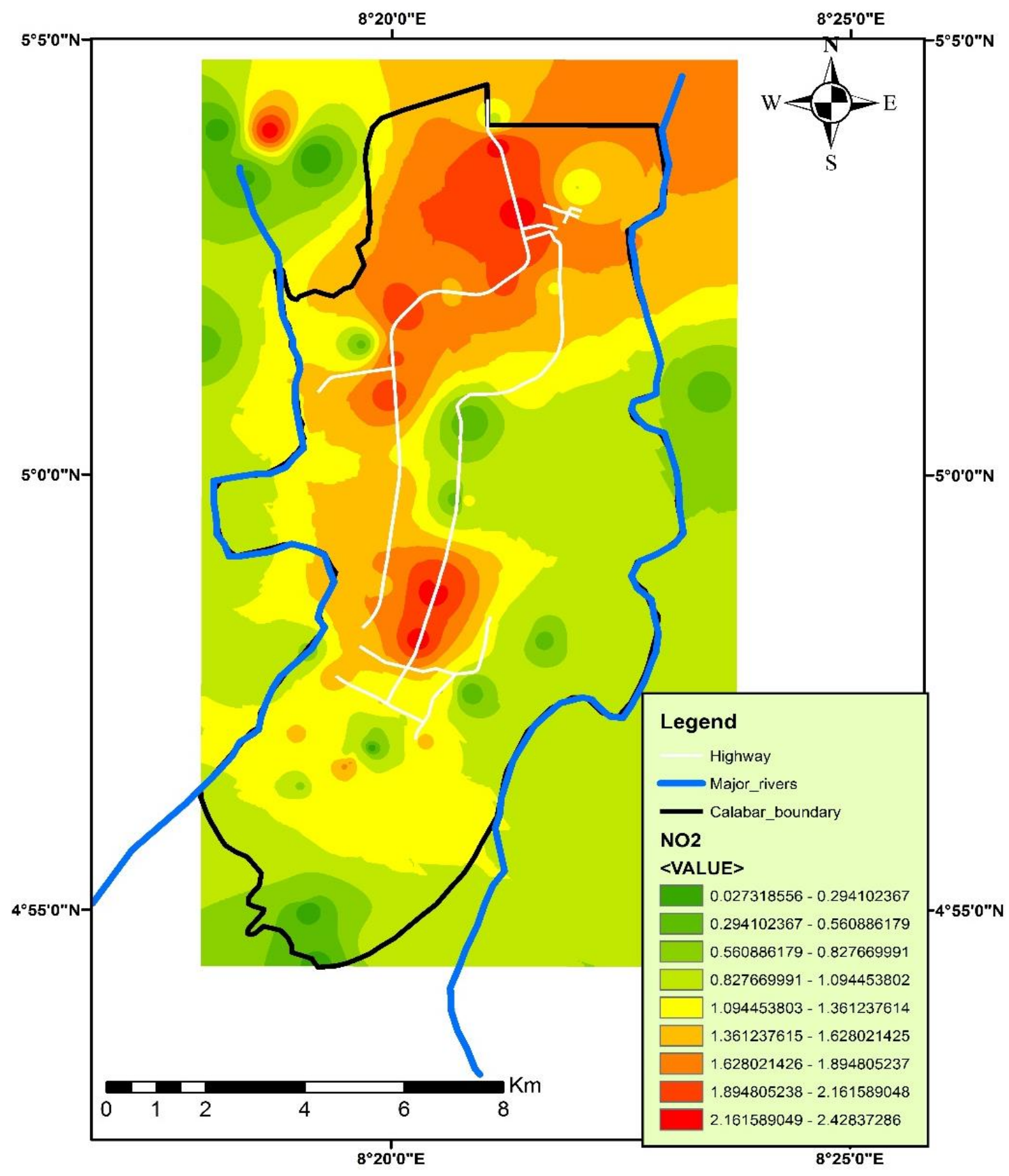

Source: Author`s GIS visualization, 2020.

Figure 9. $\mathrm{NO}_{2}$ footprints for Calabar Metropolis 


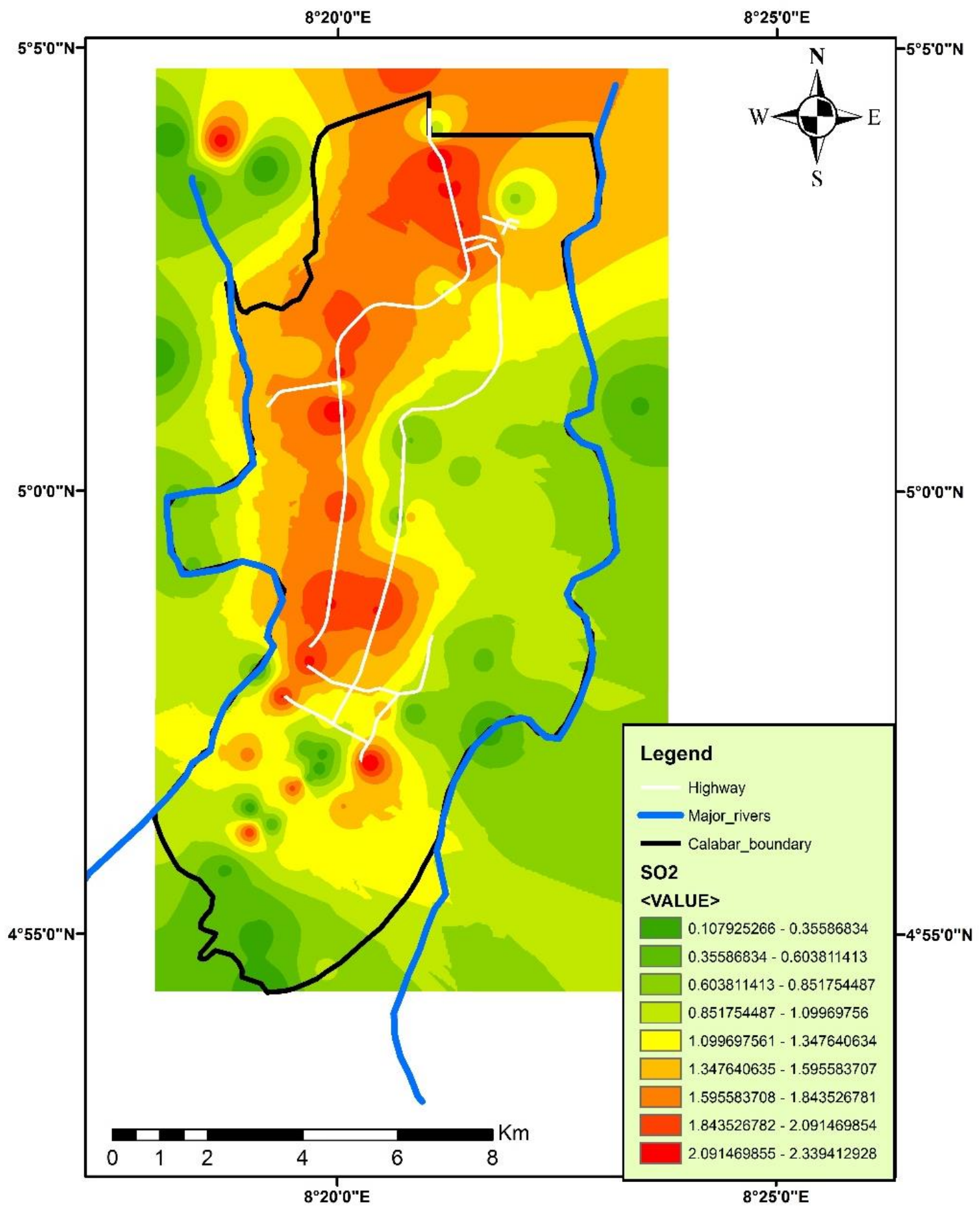

Source: Author`s GIS visualization, 2020.

Figure 10. $\mathrm{SO}_{2}$ footprints for Calabar Metropolis 


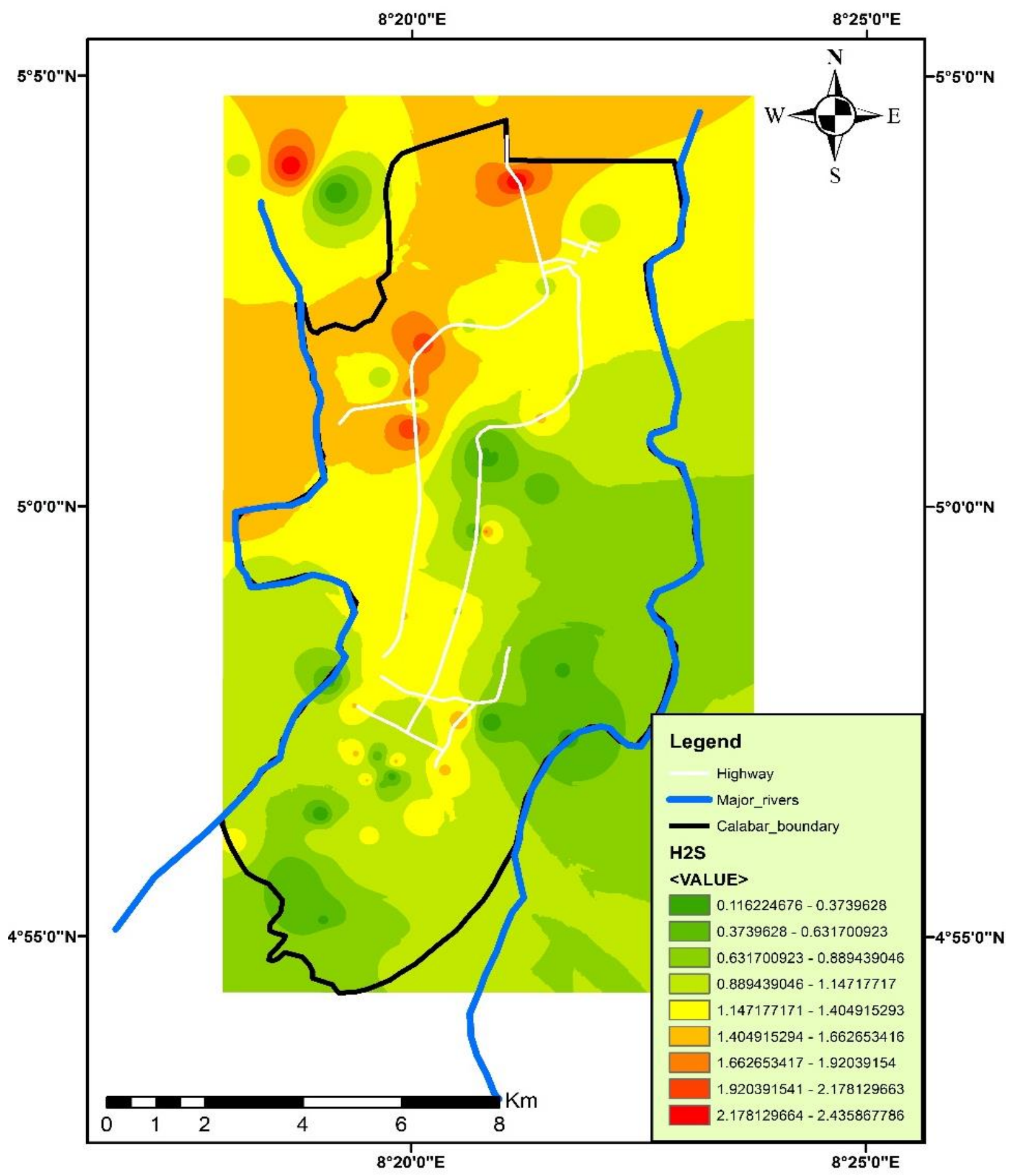

Source: Author`s GIS visualization, 2020.

Figure 11. $\mathrm{H}_{2} \mathrm{~S}$ footprints for Calabar Metropolis 


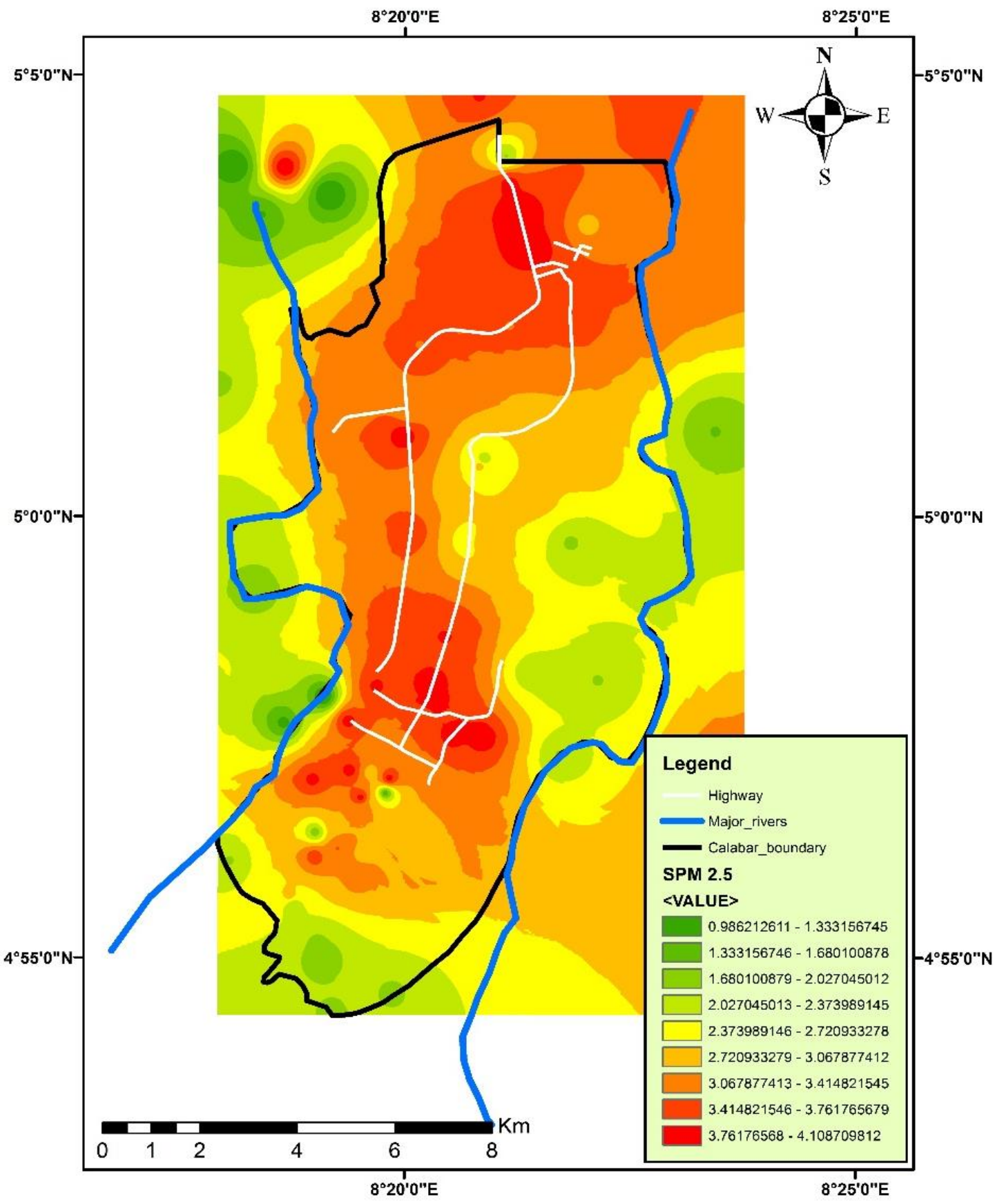

Source: Author`s GIS visualization, 2020

Figure 12. $\mathrm{SPM}_{2.5}$ footprints for Calabar Metropolis

In addition, figures $8,9,10,11$ and 12 show the air quality footprints for Calabar Metropolis. The red portion on figure 8 shows the level of $\mathrm{CO}$ concentration over the metropolis. From the footprint map, concentration of $\mathrm{CO}$ is dense in most parts of the built up area particularly along the transportation, commercial and industrial land uses. The peripheral zones in green shades have been identified to be low in CO. This interpretation is applicable to the rest of the footprints maps.

\section{Summary}

The study geospatially assessed Ambient Air Quality Footprints in Calabar Metropolis, Nigeria, in relation to existing dominant landuse elements. The major objectives were to assess the spatial variation in air quality status in relation to land use types in Calabar Metropolis, Nigeria as well as to assess the seasonality differential in air quality status in Calabar Metropolis. 
The analytical techniques took both geospatial and statistical dimensions. The outputs are in the form of 5 composite maps which depict air quality footprints for the measures parameters; as well as the results of the tests of hypotheses.

The hypothesis tested the level of significance in the variation of air quality $\left(\mathrm{CO}, \mathrm{NO}_{2}, \mathrm{SO}_{2}, \mathrm{H}_{2} \mathrm{~S}\right.$, and $\left.\mathrm{SPM}_{2.5}\right)$ in Calabar Metropolis in relation to either land use type or season of the year. Descriptive statistics for $\mathrm{CO}, \mathrm{NO}_{2}, \mathrm{SO}_{2}$, $\mathrm{H}_{2} \mathrm{~S}$, and $\mathrm{SPM}_{2.5}$ shows that their concentration is higher in the dry season than in the wet season. From further analysis, the F-ratio for season and land use for all parameters were significant at $\mathrm{p}<0.05$. For the interaction between seasons and land use (season * landuse), there was significance at $\mathrm{p}$ $<0.05$. Therefore, the alternate hypothesis which states that there is a significant variation in air quality $\left(\mathrm{CO}, \mathrm{NO}_{2}\right.$, $\mathrm{SO}_{2}, \mathrm{H}_{2} \mathrm{~S}$, and $\mathrm{SPM}_{2.5}$ ) in Calabar Metropolis in relation to either land use type or season of the year.

\section{Conclusion}

This study has been able to geospatially establish the relationship between urban land uses and ambient air quality footprints in Calabar Metropolis, Nigeria. Currently, urban centres worldwide now sing the new song of green urbanism. This cannot be attained and sustained if proper data and information on prevailing air quality status were not known. No doubt, urban planning which is geared towards allocating the right activities at the right location for the right people and at the right time cannot be achieved if information on the effects of urban land use related activities is not taken very seriously for making informed decision. For instance, the location of the residential neighbourhood of state housing estate is presently grossly inadequate as it is sandwiched almost at the hub of the city, between two areas of volumetric economic activities. Ultimately, in an event of any form of blockage of the major highway, state housing is seen as an alternative route to other destinations. This results to CO, SPM, noise and other pollution sources caused by vehicles, unlike satellite town and Ekorinim, which are off the city centre.

Therefore, based on the findings of this research, it was deduced that though within the acceptable limits, the commercial, transportation and industrial activity are the major sources of high concentration of air pollutants which would have significant implications on the integrity of the urban area if not checked or controlled. It was also discovered that seasonality has great implications on air quality. Therefore, a research of this nature should be sustained, and regularly depicted so that a sustainable, green, clean and livable urban environment would be created.

Finally, this research was limited in scope with regards to the study area, as only 2 local government areas making up Calabar metropolis were studied. Besides, data collection period covered only 6 months of the year $(3$ months in the rainy season and 3 months in the dry season).

\section{Recommendations}

Based on the findings of this research, certain mitigatory measures are therefore recommended for the purpose of ensuring a sustainable, clean and green Calabar Metropolis.

1. Residential zones should be exclusively maintained so as to avoid encroachment of incompatible uses which could lead to pollution and blight. Residential zones that have already been encroached, depending on the form of encroachment, should be reclaimed. For example, multiple exit routes should be closed to discourage motorists from using such as alternative routes to other destinations thereby causing heavy traffic and pollution.

2. Open spaces and gardens should be well maintained, preserved and protected due to their potentials in sanitizing the air by acting as green lungs.

3. There is need for a periodic and real-time monitoring and envisioning of air quality status to ensure adequate and strict compliance with standards. This would help in the enforcement of related codes once violated. It would be very helpful in the continuous acquisition of more robust datasets that could be used in pre-emptive planning of the metropolis in favour of clean air act. Finally, a more comprehensive research which would cut across the 12 calendar months should be undertaken on this theme.

\section{REFERENCES}

[1] Food and Agricultural Organization, FAO. "What is landuse?" www.fao.org/nr/land/use/en, assessed $18^{\text {th }}$ October, 2020.

[2] California Air Resources Board. "Air quality handbook on land use. California”, USA, government press, 2003.

[3] Boko G., \& Joachim M. "Air pollution and respiratory diseases in African big cities: the case of Cotonou in Benin. In: Bunch MJ, Suresh VM, Kumaran TV, eds". Proceedings of the Third International Conference on Environment and Health, Chennai, India; pp. 32-43, 2003.

[4] Chai, Z. F., Qian, Q. FS. \& Feng, X. Q. "Study of occupational health impact of atmospheric pollution on exposed workers at an iron and steel complex by using neutron activation analysis of scalp hair". Journal of Radiational Nuclear Chemistry, Vol.259, pp 153-156, 2004.

[5] Nku,C.O., Peters, E. J. \& Eshiet, A.I. "Lung function, oxygen saturation and symptoms among street sweepers in Calabar-Nigeria". Niger Journal of Physiological Sciences, Vol. 20, pp 79-84, 2005.

[6] Wiwanitkit, L., Suwansaksri, J., \& Soorgarun, S. "Cancer 
risk for Thai traffic exposed to traffic benzene vapor". Asian Pacific Journal of Cancer Preview, Vol. 6, pp 219-220, 2005.

[7] WHO Air Quality Guidelines Global Update. Report on a working meeting held in Bonn, Germany from 18 to 20th October 2004. http://unfccc.int/meetings/bonn_oct_2014/ meeting/8418.php, assessed $18^{\text {th }}$ October, 2020.

[8] Kennedy, S. M., Chambers, R. \& Du, W. "Environmental and occupational exposure: Do they affect chronic obstructive pulmonary disease differently in women and men?" Proceedings of the American Thoracic Society Vol. 4, pp. 692-694, 2007.

[9] Rojas-Rueda, D., de Nazzelle, A. \& Tainio, M. "The health risk and benefits of cycling in urban environments compared with car use: health impact assessment study". British Medical Journal, Vol. 118, pp. 1109-1116, 2011.

[10] Jansen, M., Qian, J. \& Wojciechowska-Shibuya, M. "Environmental threats to children. In: Children in the new millennium environmental impact on health". United Nations Environmental Programme, Children's Fund and World Health Organization, pp. 43-86, 2002.

[11] Yuvaraj R. M., "Assessment of Land Use/Land Cover and Its Dynamic Using Geospatial Techniques in Pudukkottai District of Tamil Nadu, India," Environment and Ecology Research, Vol. 8, No. 4, pp. 85-99, 2020. DOI: 10.13189/eer.2020.080401.

[12] Ngakan Made Anom Wiryasa, Ngakan Ketut Acwin Dwijendra, "Socio-Physical Transformation towards Sustainable Urban Morphology through Land Readjustment in Indonesia," Civil Engineering and Architecture, Vol. 9, No. 3, pp. 874-882, 2021. DOI: 10.13189/cea.2021.090329.

[13] Josiah Nwabueze Obiefuna, Gertrude Nnanjar Njar, Francis Ebuta Bisong, "Regional Trend in Ambient Air Quality Footprints in Calabar Urban, Nigeria," Environment and Ecology Research, Vol. 9, No. 4, pp. 173-185, 2021. DOI: 10.13189/eer.2021.090405.
[14] Eja, E. I.; Otu, J. E.; Eko, J. A.and Etim, I. O "Environmental Consequences of Volumetric Traffic Flow in Calabar Metropolis, Nigeria". International Multi-Disciplinary Journal, Ethiopia, Vol. 3 No. 3, pp. 200-211, 2011.

[15] Ikamaise, V. C., Akpan, I. O., Essiett, A. A. \& Uwah, I. E. "Concentrations and source apportionment of total suspended particulate matter in Calabar air basin". International Journal of Development and Sustainability, Vol. 2 No. 2, pp. 1203-1213, 2013.

[16] Obiefuna, J. N. \& Njar G. N. "The Spatio-Temporal Distribution of Urban Noise Islands in Calabar Metropolis, Nigeria". International Journal of Scientific \& Engineering Research. Vol. 9, No.3, pp. 216-226, 2018.

[17] Obiefuna, J. N; Bisong, F. E; Ettah, E. B. “A GIS Analysis of Noise Islands in Calabar Metropolis, Nigeria". Journal of Environment and Earth Science, Vol. 3, No. 12, pp. 1-8, 2013.

[18] Efiong, J., Eni, D.I., Obiefuna, J.N.\& Etu, S.J. “Geospatial modelling of landslide susceptibility in Cross River State of Nigeria" Scientific African, Vol. 14, pp. 1-14, 2021. DOI: 10.1016/j.sciaf.2021.e01032

[19] Leith, A. "A picture tells a thousand words, a map tells a million: mapping the world, one organic vartex at a time". http://geohipster.com/2015/09/21/alex-leith-a-picture-tellsa-thousand-words-a-map-tells-a-million/ assessed $18^{\text {th }}$ October, 2020.

[20] Sule, R. O. "Planning Urban facilities for Environmental Quality in Fundamentals of urban planning: Theory and practice in Nigeria." Lagos: BAAJ Intl, 2003. pp. 1-174.

[21] Stephen, D. S. \& Sundar, A. C. "Exploring land use and land cover effects on air quality in Central Alabama using GIS and remote sensing". Remote Sensing, Vol. 3, pp. 2552-2567, 2011.

[22] Udofia, E. P. "Sampling and Sampling Techniques in Applied Statistics with Multivariate Methods" Enugu, Nigeria: Immaculate Publ. LTD, 2011. pp. 172-222. 